RESIDENT

\& FELLOW

SECTION

Section Editor

Mitchell S.V. Elkind,

MD, MS

Shyam S. Moudgil, MD

Address correspondence and reprint requests to Dr. Shyam S. Moudgil, 20867 Mack Ave. Ste. 6, Grosse Pointe, MI 48236 shyammd.moudgil@stjohn.org

\title{
Teaching NeuroImages: Herpes zoster myelitis
}

Three weeks after developing zoster rash, a 34-yearold, previously healthy woman presented with right arm weakness and gait dysfunction. MRI of the cervical spine revealed abnormal cord signal (figure). CSF demonstrated lymphocytic pleocytosis, elevated immunoglobulin $\mathrm{G}$ ( $\mathrm{IgG}$ ) index, and anti-varicella zoster virus (VZV) IgG antibodies. VZV DNA was not detected. She was treated with IV acyclovir and steroids.

Herpes zoster myelitis is rare among immunocompetent hosts and is characterized by predominant ipsilateral involvement of spinal segments corresponding to the affected dermatome. Presence of either VZV DNA or anti-VZV IgG in the CSF is diagnostic. ${ }^{1}$
Treatment with acyclovir and corticosteroids is recommended, based on anecdotal experience. ${ }^{2}$ Corticosteroids should be used only in combination with acyclovir to prevent viral dissemination.

\section{REFERENCES}

1. Haug A, Mahalingam R, Cohrs RJ, Schmidt DS, Corboy JR, Giden D. Recurrent polymorphonuclear pleocytosis with increased red blood cells caused by varicella zoster virus infection of the central nervous system: case report and review of literature. J Neurol Sci 2010;292: $85-88$.

2. Dworkin RH, Johnson RW, Breuer J, et al. Recommendations for the management of herpes zoster. Clin Infect Dis 2007;44(suppl 1):S1-S26.

Figure Cervical zoster
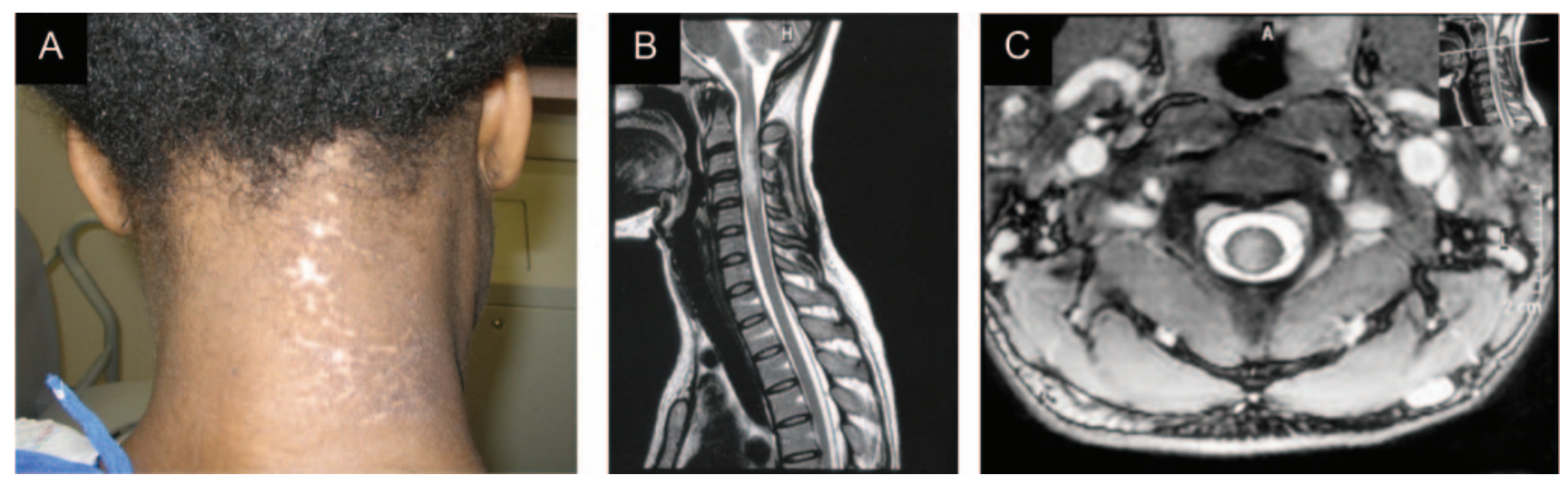

Healed herpes zoster lesions involving the right C3 dermatome (A) andT2-weighted midsagittal (B) and axial (C) MRI of the cervical spine showing hyperintense signal change in the spinal cord from $\mathrm{C} 2$ to $\mathrm{C} 4$ level with predominant involvement of the right hemicord. 


\title{
Neurology
}

\author{
Teaching NeuroImages: Herpes zoster myelitis \\ Shyam S. Moudgil \\ Neurology 2010;75; 555 \\ DOI 10.1212/WNL.0b013e3181f4d894
}

This information is current as of September 27, 2010

Updated Information \&

Services

References

Subspecialty Collections

Permissions \& Licensing

Reprints including high resolution figures, can be found at: http://n.neurology.org/content/75/13/e55.full

This article cites 2 articles, 0 of which you can access for free at: http://n.neurology.org/content/75/13/e55.full\#ref-list-1

This article, along with others on similar topics, appears in the following collection(s):

Cerebrospinal Fluid

http://n.neurology.org/cgi/collection/cerebrospinal_fluid

MRI

http://n.neurology.org/cgi/collection/mri

Spinal cord infection

http://n.neurology.org/cgi/collection/spinal_cord_infection

Viral infections

http://n.neurology.org/cgi/collection/viral_infections

Information about reproducing this article in parts (figures,tables) or in its entirety can be found online at:

http://www.neurology.org/about/about_the_journal\#permissions

Information about ordering reprints can be found online:

http://n.neurology.org/subscribers/advertise

Neurology ${ }^{\circledR}$ is the official journal of the American Academy of Neurology. Published continuously since 1951, it is now a weekly with 48 issues per year. Copyright . All rights reserved. Print ISSN: 0028-3878. Online ISSN: 1526-632X.

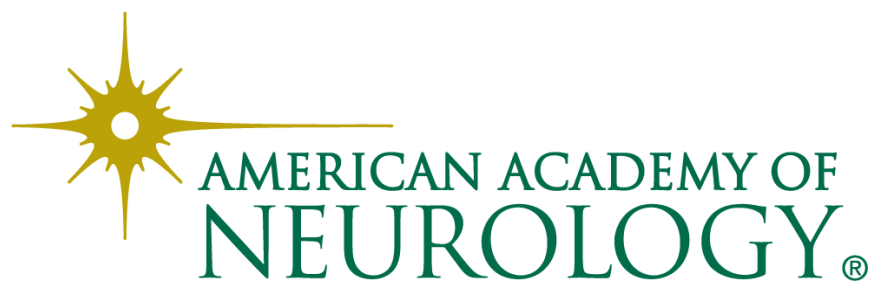

